\title{
Intensification of Nickel Bioleaching with Neutrophilic Bacteria Guyparkeria halophila as an Approach to Limitation of Sulfuric Acid Pollution
}

\author{
Tatiana Abashina, Alyona Yachkula (D), Elena Kaparullina and Mikhail Vainshtein *(D) \\ Federal Research Center "Pushchino Scientific Center for Biological Research of the Russian Academy of \\ Sciences", Skryabin Institute of Biochemistry and Physiology of Microorganisms, Microorganisms Russian \\ Academy of Sciences, Prospect Nauki 5, 142290 Pushchino, Russia; tnabashina@gmail.com (T.A.); \\ repinaalenk@mail.ru (A.Y.); lenokap80@gmail.com (E.K.) \\ * Correspondence: vain@ibpm.pushchino.ru
}

check for updates

Citation: Abashina, T.; Yachkula, A.; Kaparullina, E.; Vainshtein, M. Intensification of Nickel Bioleaching with Neutrophilic Bacteria

Guyparkeria halophila as an Approach to Limitation of Sulfuric Acid Pollution. Microorganisms 2021, 9 , 2461. https://doi.org/10.3390/ microorganisms 9122461

Academic Editor: Hermann J. Heipieper

Received: 27 October 2021 Accepted: 25 November 2021 Published: 29 November 2021

Publisher's Note: MDPI stays neutral with regard to jurisdictional claims in published maps and institutional affiliations.

Copyright: (c) 2021 by the authors. Licensee MDPI, Basel, Switzerland. This article is an open access article distributed under the terms and conditions of the Creative Commons Attribution (CC BY) license (https:// creativecommons.org/licenses/by/ $4.0 /)$.

\begin{abstract}
Hydrometallurgical production of valuable and non-ferrous metals is traditionally accompanied with acid waste effluents / acid mine drainage leading to acidification of the mining areas. The traditional cause of this pollution is the well-known technology based on the recovery of metals with acid solutions and the application of strong acidophilic leaching bacteria for the oxidation of sulfide ores. In our experiments, we used neutrophilic autotrophic bacteria (NAB) stimulated with formic acid or coupled with acidophilic bacteria. The first approach was based on using formic acid as an energetic substrate by autotrophic bacteria. In the second case, the NAB provided initial biogenic acidification for the following growth of the inoculated acidophilic bacteria. Our experiments resulted in increased nickel recovery from the low-grade sulfide ores, which was provided by the NAB in a medium supplemented with formic acid. Bioleaching resulted in $1116 \mathrm{mg} \mathrm{Ni} / \mathrm{L}(69.75 \%)$ in the medium with formate and only $35.4 \mathrm{mg} \mathrm{Ni} / \mathrm{L}$ without formate in 43 days. As a whole, our bench scale experiments showed that the stimulated NAB can be effective at $\mathrm{pH} 7-5$. Partially replacing sulfuric acid with formic acid could also give benefits via the following natural degradation of acid wastes. As a whole, this approach is more environmentally friendly than conventional bioleaching techniques.
\end{abstract}

Keywords: nickel bioleaching; low-grade ore; formic acid; Guyparkeria halophila

\section{Introduction}

Hydrometallurgical mining processing produces acid waste effluents/acid mine drainage. In turn, these effluents provoke a large-scale technogenic catastrophe: acidification of the mining areas with strong inorganic acids, usually-with sulfuric acid [1,2]. The traditional technique for metal recovery from the low-grade sulfide ores was chemical leaching with strong acids; since the 1950s [3], this chemical leaching has been partly replaced with bioleaching, i.e., the application of acid-producing leaching microorganisms. The leading industrial species of these microorganisms are presented with acidophilic autotrophic bacteria or archaea. The choice was provided by the following characteristics of industrial significance: (i) strong acidophilic bacteria produce sulfuric acid by the oxidation of mineral sulfides and/or increase redox values by iron oxidation and (ii) bacterial autotrophy excludes any need to support the industrial process with organic growth substrates. During bioleaching of sulfide ores, strong acidophilic bacteria oxidize mineral sulfides to sulfuric acid, with an essential $\mathrm{pH}$ decrease and environment acidification. Attempts to expand the diversity of industrial leaching moderately acidophilic bacteria were not successful enough to replace strong acidophilic species such as Acidithiobacillus ferrooxidans, which can oxidize both mineral sulfides and $\mathrm{Fe}^{2+}$, grow at $\mathrm{pH}<3.0$, and synthesize its biomass from carbon dioxide $[4,5]$. 
For decades, microbiological renovations were focused on (i) the search for more effective acidophilic species and strains [6-8] or (ii) optimization of the processing regimes [9-11]. Good examples of these approaches are presented in some modern research investigations where authors used (i) a new Sulfobacillus strain, (ii) a higher temperature $\left(47^{\circ} \mathrm{C}\right)$, and (iii) low pH (1.8) [12]. Some approaches also included combinations of different microorganisms such as acidophilic chemolithotrophic and heterotrophic strains (Sulfobacillus thermosulfidooxidans and Thermoplasma acidophilum) [13].

Three decades ago, Pronk with coauthors [14] had already shown that the growth of $A$. ferrooxidans (former name Thiobacillus ferrooxidans) can be stimulated with formic acid. By the published data [14], formic acid, as an organic compound, was not used as a growth substrate but it provided some energetic needs. Moreover, the mentioned authors also proposed pre-growing $A$. ferrooxidans with formate for the following metal leaching from ores and claimed this approach with a patent [15]. This increase in the activity of acidobacilli with formate served as the starting point for the presented study.

Sulfuric acid supplementation is essential to provide low $\mathrm{pH}$ values for strictly acidophilic leaching bacteria ( $\mathrm{pH}$ optimum 1-2). In this regard, we studied the stimulation of neutrophilic autotrophic bacteria (NAB). The studied bacteria, Guyparkeria halophila VKM B-2757D, are known as NAB that oxidize reduced sulfur compounds, including sulfide, to sulfuric acid at pH optimum 7.0-7.3 [16]. Additionally, this species is moderately halophilic, which is favorable since the process increases total mineralization of the leaching solution. Our data on nickel bioleaching from the low-grade sulfide ores showed an intensification of nickel recovery by the NAB despite the limited input of sulfuric acid. The developed approach seems to be a kind of eco-friendly technology because it both decreases the input of sulfuric acid and simplifies the following acid waste disposal.

\section{Materials and Methods}

\subsection{Mineral Materials}

Samples of the low-grade sulfide nickel ore, $0.8 \% \mathrm{Ni}$, were presented by CANMETMining and Mineral Sciences Laboratories. Mineral composition of the ore is presented in the Table 1 for the most essential compounds. Mechanical composition of the samples was represented by a fine $(<1 \mathrm{~mm})$ fraction.

Table 1. Essential components of the low-grade sulfide nickel ore (CANMET-Mining and Mineral Sciences Laboratories).

\begin{tabular}{clcc}
\hline \multirow{2}{*}{ Nos. } & \multicolumn{2}{c}{ Minerals } & Concentration, wt \% \\
\cline { 2 - 4 } & Name & Composition & \\
\hline 1 & pyrrhotite & $\mathrm{Fe}_{(1-\mathrm{x})} \mathrm{S}$ & 33.0 \\
2 & plagioclase & $(\mathrm{Na}, \mathrm{Ca}) \mathrm{AlSi}_{3} \mathrm{O}_{8}$ & 22.0 \\
3 & hornblende & $\mathrm{Ca}_{2}(\mathrm{Mg}) \mathrm{O}-2(\mathrm{Fe})_{2}-4\left(\mathrm{Al}, \mathrm{Fe}_{(}\right)\left(\mathrm{Si}_{7} \mathrm{Al}\right) \mathrm{O}_{22}(\mathrm{OH})_{2}$ & 13.0 \\
4 & hypersthene & $(\mathrm{Mg}, \mathrm{Fe}) \mathrm{SiO}_{3}$ & 5.0 \\
5 & pentlandite & $\left(\mathrm{Fe}, \mathrm{Ni}_{9} \mathrm{~S}_{8}\right.$ & 3.0 \\
6 & chalcopyrite & $\mathrm{CuFeS}$ & 0.7 \\
\hline
\end{tabular}

\subsection{Microorganisms and Culturing Media}

Two bacterial strains were used in the leaching experiments, namely: Guyparkeria halophila VKM B-2757D and Acidithiobacillus sp. KZ-02. The last of these was originated from the acid mine drainage, ore deposit Aksu (isolated by I. Korovkina, "National Center for Biotechnology of the Republic of Kazakhstan").

Neutrophilic strain G. halophila was cultured in the medium DSM 518 (g/L): $\mathrm{Na}_{2} \mathrm{HPO}_{4}$. $2 \mathrm{H}_{2} \mathrm{O}, 7.9 ; \mathrm{KH}_{2} \mathrm{PO}_{4}, 1.5 ; \mathrm{NaCl}, 50 ; \mathrm{MgSO}_{4}, 0.1 ; \mathrm{NH}_{4} \mathrm{Cl}, 0.4 ; \mathrm{Na}_{2} \mathrm{~S}_{2} \mathrm{O}_{3}$ (anhydrate), 5.0; trace element solution, $5.0 \mathrm{~mL} ; \mathrm{pH}$ was adjusted to 7.0. The $10 \%$ solutions of $\mathrm{MgSO}_{4} \cdot 7 \mathrm{H}_{2} \mathrm{O}$, $\mathrm{NH}_{4} \mathrm{Cl}, \mathrm{CaCl}_{2} \cdot 2 \mathrm{H}_{2} \mathrm{O}$, and $25 \% \mathrm{Na}_{2} \mathrm{~S}_{2} \mathrm{O}_{3}$ were sterilized separately and added to the main volume of the medium after sterilization. $\mathrm{pH} 7.0$ was chosen in accordance with the species characteristics [16]. 
Acidophilic strain Acidithiobacillus sp. KZ-02 (pH optimum 4.5) was cultured in synthetic mineral medium of the following composition (g/L): $\mathrm{KH}_{2} \mathrm{PO}_{4}-0.5 ; \mathrm{NH}_{4} \mathrm{Cl}-0.5$; $\mathrm{MgSO}_{4} \cdot 7 \mathrm{H}_{2} \mathrm{O}-0.25 ; \mathrm{Na}_{2} \mathrm{~S}_{2} \mathrm{O}_{3} \cdot 5 \mathrm{H}_{2} \mathrm{O}-5.0 ; \mathrm{NaCl}-0.5$. The medium $\mathrm{pH}$ was 5.0. To adjust $\mathrm{pH}$ to the desired value, $\mathrm{H}_{2} \mathrm{SO}_{4}$ was used.

\subsection{Leaching Experiments}

In experiments with the NAB culture G. halophila, $40 \mathrm{~g}$ dry ore samples were placed into $750 \mathrm{~mL}$ flasks with $200 \mathrm{~mL}$ leaching solution, i.e., the solid and liquid phases were at a ratio of 1:5. As mentioned above, mechanical composition of the samples was represented by a fine $(<1 \mathrm{~mm})$ fraction and the nickel content was $0.8 \%$. Theoretical maximum amount of nickel in solution could reach $1600 \mathrm{mg} / \mathrm{L}$. All experiments were conducted in triplicate under aerobic conditions at $28^{\circ} \mathrm{C}$ on a shaker IBPM (IBPM, Pushchino, Russia) at $180 \mathrm{rpm}$. Thus, the process was a model of vat leaching at constant temperature. These experiments included comparison of nickel leaching in the culturing medium DSM 518 with formate $(0.3 \%)$ and without formate (blank). Inoculate was $10 \mathrm{~mL}$ of this mineral medium with $10^{6}-10^{7}$ cells $/ \mathrm{mL}$.

In two-step experiments combining NAB and acidophilic bacteria, at the first step, the flask with ore was inoculated with G. halophila culture. The second step of the experiment: when $\mathrm{pH}$ decreased from 7 to 5, the flask was additionally inoculated with Acidithiobacillus sp. KZ-02. Experimental conditions were the same as described above.

The control (blank) experiments were presented as versions without inoculation.

\subsection{Nickel Analyzes}

The aim of the study was the leaching of nickel, since its extraction was of not only scientific but also industrial interest. We did not assess leaching of associated metals. Nickel concentrations in solution were analyzed with ion chromatography. The ion chromatography analyses were performed with device Compact IC, columns 6.1010.300 Metrosep: $3 \times$ $9 \times 150 \mathrm{~mm}$ (Metrohm, Herisau, Switzerland).

\subsection{Enzyme Activity Analyzes}

Bacterial cells were harvested at the beginning of the stationary growth stage and precipitated by centrifugation at $6000 \mathrm{~g}$ for $15 \mathrm{~min}$; then they were washed with buffer solution and re-suspended. At the next step, the cells were disrupted by a Qsonica S4000 sonicator (Qsonica LLC, Newtown, CT, USA) in tubes placed in ice. The disruption procedure was repeated 6 times, $30 \mathrm{~s}$ each, at 1 min intervals. Unbroken cells were separated by centrifugation at $14,000 \mathrm{~g}$ for $40 \mathrm{~min}$. The resultant supernatant was used as a target extract to analyze the enzyme activity. Formate dehydrogenase was estimated by the reduction of 2,6-dichlorophenolindophenol (DCPIP) [13]. The reaction mixture contained $(\mu \mathrm{M})$ : phosphate buffer ( $\mathrm{pH} 7.0), 50.0$; DCPIP, 0.075; phenazine methosulfate (PMS), 0.5; formate as substrate, 50.0; cell extract. $\mathrm{NAD}^{+}$-dependent formate dehydrogenase was estimated by reduction of $\mathrm{NAD}^{+}[17]$. The reaction mixture contained $(\mu \mathrm{M})$ : tris- $\mathrm{HCl}$ buffer ( $\mathrm{pH} 7.5), 50.0$; NAD, 0.25 ; formate as substrate, 50; cell extract. The reactions were started by addition of formate. The protein content was determined by a modified Lowry method [18].

\subsection{Optical Density Analyses}

Optical density (OD) of the culture was measured using Spekol 221 spectrophotometer (Carl Zeiss Industrielle Messtechnik $\mathrm{GmbH}$, Jena, Germany) at wavelength $600 \mathrm{~nm}$. The data are the mean values of triplicate experiments and duplicate determinations, variations were within the limits of $5 \%$. 


\subsection{Statistics}

The experiments and analyses were performed in triplicate. All data were statistically checked and the presented results showed a high level of reliability: $p>0.99$ (ANOVA, Excel Microsoft). Error bars are shown in the Figures.

\section{Results and Discussion}

\subsection{Stimulation of Bacterial Growth with Formate}

It is already known that autotrophic A. ferrooxidans ATCC 21834 (former name Thiobacillus ferrooxidans) uses organic compound, formate, as a source of energy $[14,15]$. This way of formate consumption was suggested by Pronk with coauthors [14] because the studied bacteria were stimulated by formate and contained phenazine methosulfate (PMS) formate dehydrogenase. We investigated if moderate acidophilic autotrophic bacteria G. halophila VKM B-2757D could also be stimulated with formate. The experiments showed stimulation of the bacterial growth with $0.3 \%$ formate in the DSM 518 medium and the growth depression with $0.6 \%$ (Figure 1). Enzyme activity of the formate dehydrogenase was investigated and compared with the published data on A. ferrooxidans ATCC 21834 (Table 2).

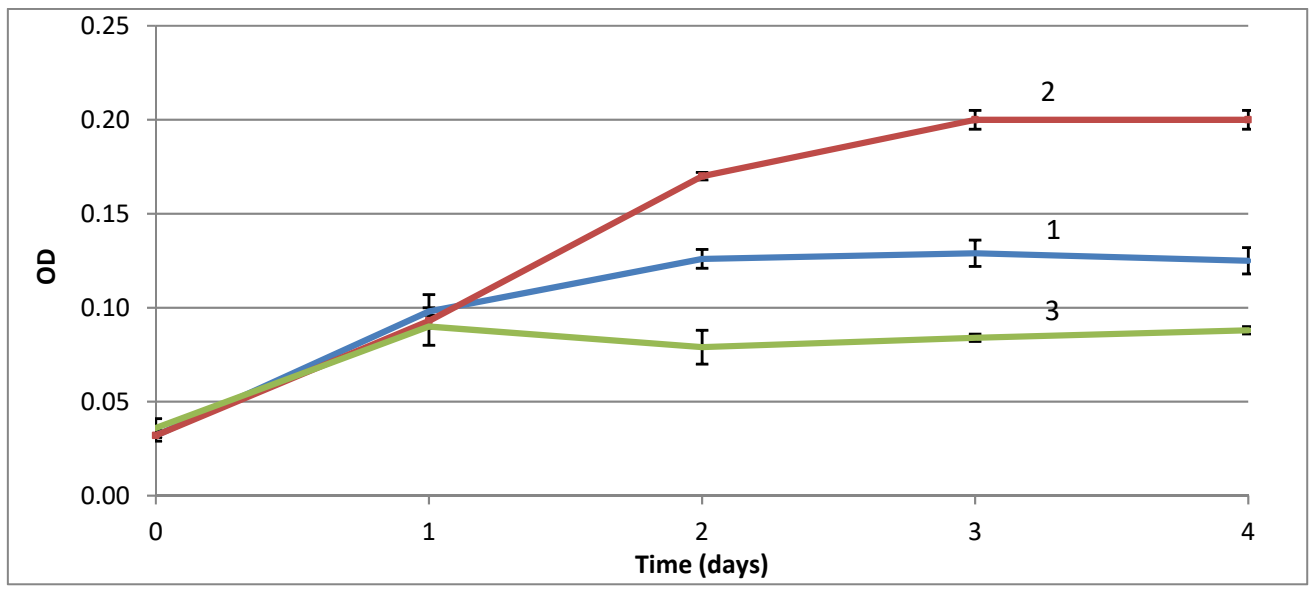

Figure 1. Effects of formate on growth dynamics of G. halophila measured by optical density in the medium DSM 518. Abscissa axis: time (days); ordinate axis: optical density (OD), $\lambda=600 \mathrm{~nm}$. Formate concentrations, \%: $1-0.0 ; 2-0.3 ; 3-0.6$. Error bars are shown in the Figure.

Table 2. Activities of formate dehydrogenase in extracts of autotrophic bacteria.

\begin{tabular}{|c|c|c|c|}
\hline \multirow[b]{2}{*}{ Enzyme } & \multirow[b]{2}{*}{ Cofactors } & \multicolumn{2}{|c|}{ Activity, $\mathrm{nM} / \mathrm{min} \cdot \mathrm{mg}$ of Protein } \\
\hline & & $\begin{array}{l}\text { A. ferrooxidans } \\
\text { ATCC } 21834 \text { [14] }\end{array}$ & $\begin{array}{c}\text { G. halophila } \\
\text { VKM B-2757D }\end{array}$ \\
\hline Formate & PMS & 80 (max.) & 18 \\
\hline dehydrogenase & $\mathrm{NAD}^{+}$ & 0 & 0 \\
\hline
\end{tabular}

Thus, following data published by Pronk with coauthors [14], we also may conclude that bacteria G. halophila oxidize formate but do not use it for direct biomass synthesis. It is interesting to note, however, that the initial composition of the medium does not include carbonate, i.e., carbon as a growth substrate is limited with dissolution of $\mathrm{CO}_{2}$ in the acid culturing medium. At the same time, the oxidation of formate to carbon dioxide not only supplies the bacteria with energy but also provides an increased concentration of $\mathrm{CO}_{2}$ directly on the cell surface. We can assume that formate is not only an energy substrate but also a precursor of a growth substrate. 


\subsection{Stimulation of Ni Leaching by G. halophila with Formic Acid}

The whole study was oriented to limitation of the sulfuric acid input for the metal leaching process. Our main approach was based on the application of NAB, which grows at neutral or moderate low $\mathrm{pH}$. As was shown above, stimulation with $0.3 \%$ formate increased growth 2.5-fold in 4 days (Figure 1). These data were a logical basis for the nickel leaching from low-grade sulfide ore using formate-stimulated NAB. The results of the experiments are presented in Figure 2. The medium $\mathrm{pH}$ decreased together with bacterial sulfate production, and in 14 days, $\mathrm{pH}$ values reached 5.8 and 6.2 in variants with and without formate, respectively. Sulfate production reached $3271 \pm 25$ and $2235 \pm 14$ $\mathrm{mg} \mathrm{SO}_{4}{ }^{2-} / \mathrm{L}$, respectively, in 14 days and increased up to $7557 \pm 52$ and $3532 \pm 22 \mathrm{mg}$ $\mathrm{SO}_{4}{ }^{2-} / \mathrm{L}$ in 43 days. Similarly, concentrations of dissolved nickel were $3.10 \pm 0.4$ and 0.86 $\pm 0.07 \mathrm{mg} / \mathrm{L}$, respectively, in 14 days. Prolonged processing resulted in $1116 \pm 8 \mathrm{mg} \mathrm{Ni} / \mathrm{L}$ in the medium with formate and only $35.4 \pm 0.5 \mathrm{mg} \mathrm{Ni} / \mathrm{L}$ without formate in 43 days (Figure 2). The presented result of the maximum nickel yield is equal to $69.75 \%$ of the full nickel content. It is interesting to compare our results with the data on bioleaching by strictly acidophilic $A$. ferrooxidans without formate. A good example is presented by Yanishevskya with coauthors [19] where nickel yield from sulfide ores was $22.5 \%$. This result is 10 times higher than our nickel yield without formate $(2.21 \%)$, but three times lower than our yield with formate.
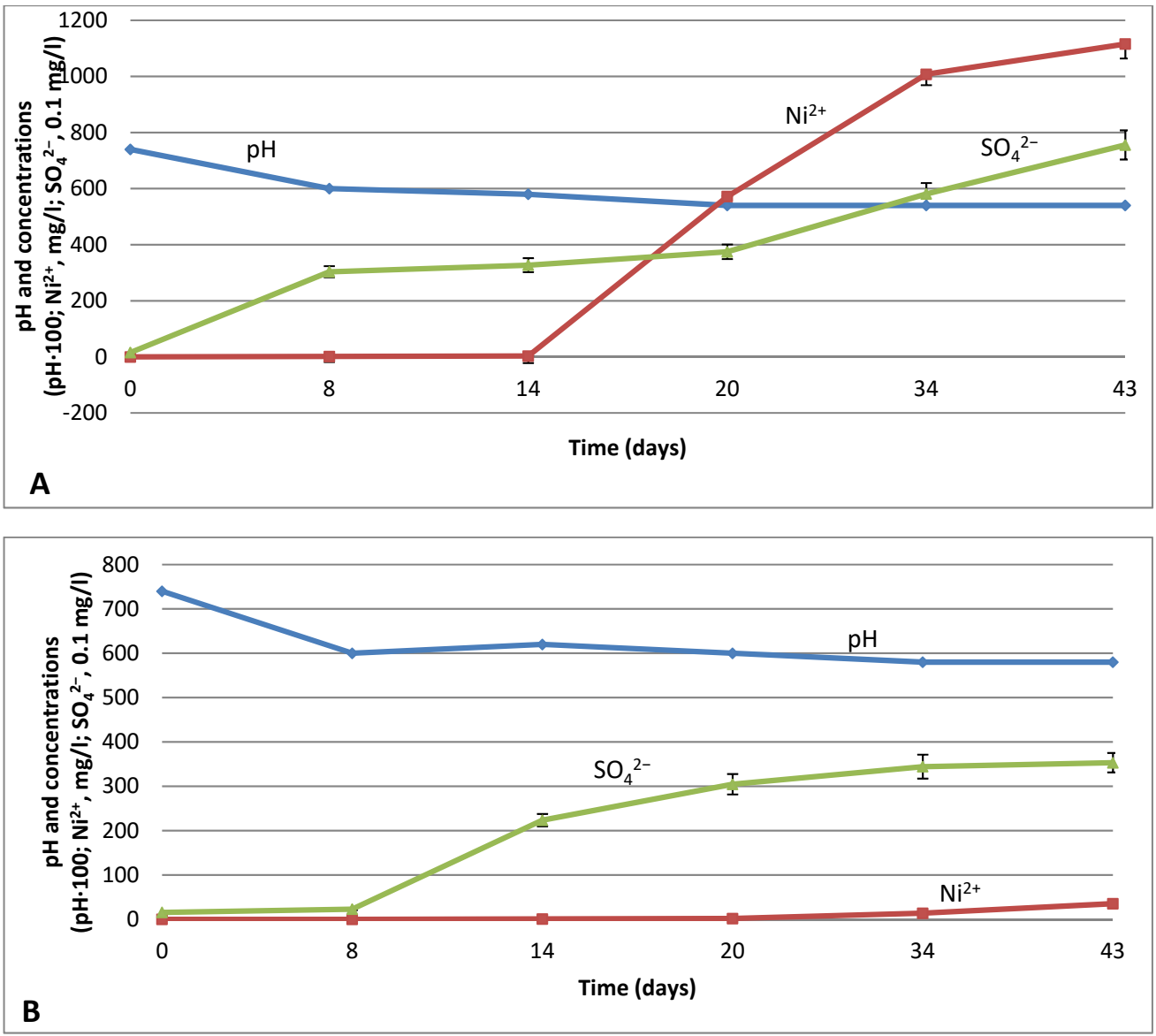

Figure 2. Effects of formate supplementation on bioleaching of sulfide nickel ore inoculated with G. halophila. (A) medium DSM 518 supplemented with formate, 0.3\%. (B) medium DSM 518 without formate (blank). Abscissa axis: time (days); ordinate axis: concentrations and $\mathrm{pH}\left(\mathrm{Ni}^{2+}, \mathrm{mg} / \mathrm{L}\right.$; $\left.\mathrm{SO}_{4}{ }^{2-}, \mathrm{mg} / \mathrm{L} \times 0.1 ; \mathrm{pH} \times 100\right)$. Error bars are shown in the Figure (some error values are too small to be distinctive). 
When the initial $\mathrm{pH}$ value was neutral ( $\mathrm{pH} 7.0-7.5)$, no changes in nickel and sulfate concentrations, or in $\mathrm{pH}$, were discovered in the uninoculated (blank) versions during exposition.

\subsection{Subsequent Leaching with Neutrophilic Bacteria G. halophila and Acidophilic Bacteria Acidithiobacillus sp.}

Traditional metal leaching is carried out by the acidic degradation of minerals and solution of metals in the acid leaching solution. Thus, strong acidophilic chemolithotrophic bacteria leach metals from sulfide ores via the oxidation of sulfides to sulfuric acid. As far as industrial leaching strains need low initial $\mathrm{pH}$, the processing is provided with the supplementing of strong acids (sulfuric acid).

The isolated strain Acidithiobacillus sp. KZ-02 was acidophilic and did not grow at $\mathrm{pH}$ above 5.0. Initial medium $\mathrm{pH}$ was 7.5, so, we inoculated the medium with NAB, waited till they decreased $\mathrm{pH}$ to 5.0 and then inoculated it additionally with Acidithiobacillus sp. KZ-02. The data of the experiment are shown in Figure 3.

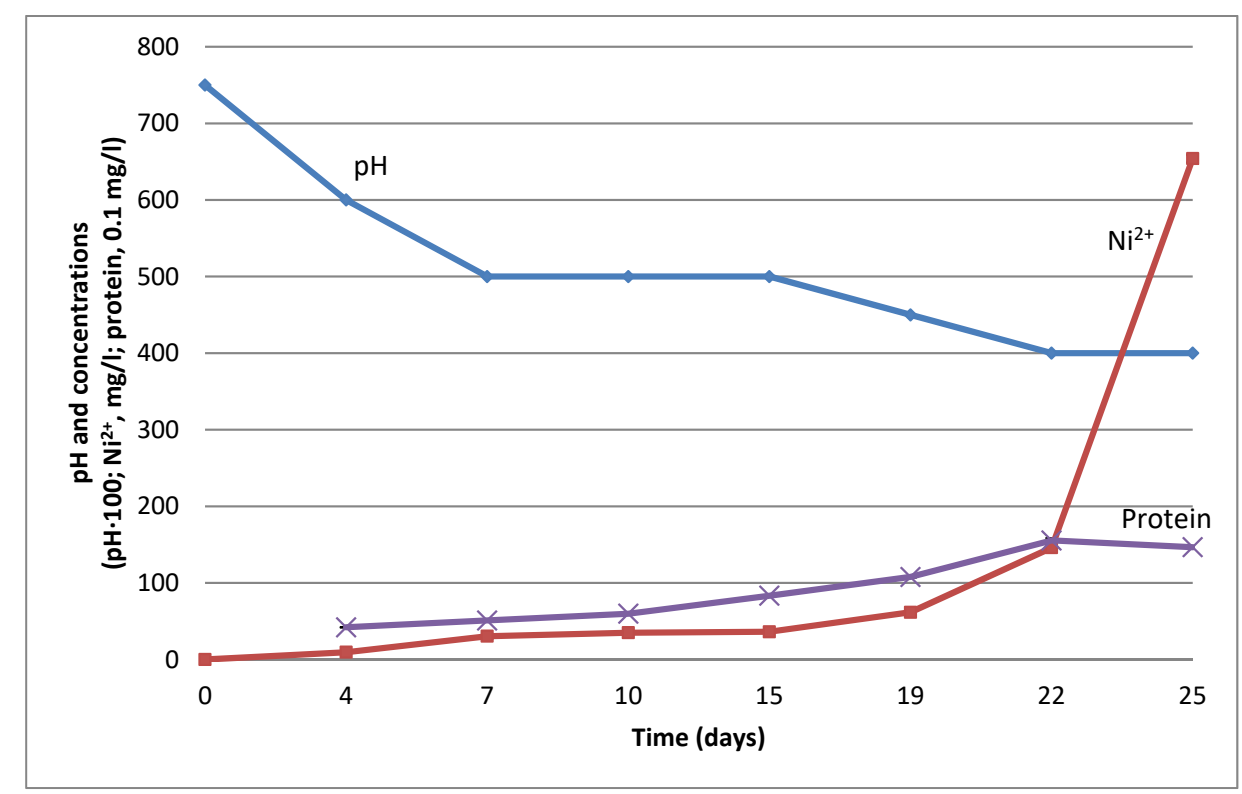

Figure 3. Two-step Ni bioleaching from the low-grade sulfide ore. The sample was initially inoculated with G. halophila VKM B-2757D and additionally inoculated with Acidithiobacillus sp. KZ-02 (at the 15 th day, shown in the figure with arrow). Abscissa axis: time (days); ordinate axis: concentrations and $\mathrm{pH}\left(\mathrm{Ni}^{2+}, \mathrm{mg} / \mathrm{L}\right.$; protein, $\left.\mathrm{mg} / \mathrm{L} ; \mathrm{pH} \times 100\right)$. Error bars in the Figure are too small to be distinctive.

Ore inoculation with the NAB G. halophila VKM B-2757D resulted in the $\mathrm{pH}$ decreasing from 7.5 to a stable 5.0 in ten days. The process of Ni leaching also came to a plateau in ten days. At the 15th day, the following inoculation with Acidithiobacillus sp. KZ-02 resulted in the next step of $\mathrm{pH}$ decreasing and additional Ni leaching (Figure 3).

Figure 3 shows that the increase in biomass (protein) was linear and stabilized at the last stage ( $\mathrm{pH} 4$ ) when the leaching rate sharply increased. Thus, we can assume that, in this case, the leaching increase was not determined by biomass growth directly.

We showed that $\mathrm{pH} 5.0$ for acidophilic bacteria can be provided with the initial NAB inoculation without the additional input of sulfuric acid. These results show an approach to limit the input of sulfuric acid, however, they do not present a final solution of the whole industrial problem because NAB did not decrease $\mathrm{pH}$ lower than 5.0, while strong acidophilic bacteria such as $A$. ferrooxidans need a $\mathrm{pH}<3.0$.

Hydrometallurgical mining of valuable and non-ferrous metals by leaching is traditionally accompanied with acid effluent wastes. Pollution of mining territories with sulfuric acid is a global problem. The known attempts to replace strong sulfuric acid with organic 
acids and/or neutrophilic leaching bacteria, failed because of the weak leaching effect. In our experiments, we showed the intensification of nickel leaching by NAB G. halophila with bacterial stimulation. The formate-stimulated bioprocessing increased nickel production at $\mathrm{pH}$ 5.0-5.4. Pronk with coauthors $[14,15]$ showed that formate is an additional source of energy for autotrophic bacteria. We suggest that, as well, it is a precursor of growth substrate $\left(\mathrm{CO}_{2}\right.$ provided via formate degradation). As a whole, the experimental results showed that metal bioleaching can be intensified with the limited application of sulfuric acid.

\section{Conclusions}

Bench scale experiments showed that a high recovery of nickel from low-grade sulfide ores can be reached with stimulation of the leaching activity of neutrophilic bacteria $G$. halophila formate supplement. The leaching process was conducted within $\mathrm{pH}$ limits $7 \rightarrow 5$, which are favorable for environmental safety in nickel bioleaching. Nickel yield reached $69.75 \%$ of its content in the ore in 43 days. Increasing leaching activity may be explained by an increasing yield of bacteria, when the formate could serve both as a supplemented source of energy [14,15] and a precursor of growth substrate for autotrophic bacteria $\left(\mathrm{CO}_{2}\right.$ provided via formate degradation). This approach is interesting both for increasing leaching efficiency and for reducing industrial sulfuric acid pollution.

Author Contributions: All authors contributed substantially to the work, namely: ConceptualizationM.V. and T.A.; Methodology-M.V., A.Y. and E.K.; Analyses and Investigation-A.Y. and E.K.; Writing, Original Draft Preparation-M.V., T.A. and E.K.; Supervision and Project Administration-M.V. All authors have read and agreed to the published version of the manuscript.

Funding: The presented research work was supported with grant No. 075-15-2021-968 provided by the Ministry of Science and Higher Education of the Russian Federation.

Institutional Review Board Statement: Not applicable.

Informed Consent Statement: Not applicable.

Data Availability Statement: Not applicable.

Conflicts of Interest: The authors declare no conflict of interest.

\section{References}

1. Fuchs, W. Process of Leaching Sulfide Containing Materals with Hot, Strong Sulfuric Acid. U.S. Patent 3,726,667, 10 April 1973. Available online: https:/ / patents.google.com/patent/US3726667A/en (accessed on 15 November 2021).

2. Liu, F.; Qiao, X.; Zhou, L.; Zhang, J. Migration and Fate of Acid Mine Drainage Pollutants in Calcareous Soil. Int. J. Environ. Res. Public Health 2018, 15, 1759. [CrossRef] [PubMed]

3. Zimmerley, S.; Wilson, D.; Prater, J. Cyclic Leaching Process Employing Iron-Oxidizing Bacteria. U.S. Patent 2,829,964, 8 April 1958. Available online: https:// patents.google.com/patent/US2829964A/en (accessed on 15 November 2021).

4. Campodonico, M.A.; Vaisman, D.; Castro, J.F.; Razmilic, V.; Mercado, F.; Andrews, B.A.; Feist, A.M.; Asenjo, J.A. Acidithiobacillus ferrooxidans's comprehensive model driven analysis of the electron transfer metabolism and synthetic strain design for biomining applications. Metab. Eng. Commun. 2016, 3, 84-96. [CrossRef] [PubMed]

5. Monachon, M.; Albelda-Berenguer, M.; Joseph, E. Chapter One-Biological oxidation of iron sulfides. In Advances in Applied Microbiology; Gadd, G.M., Sariaslani, S., Eds.; Academic Press: Cambridge, MA, USA, 2019; Volume 107, pp. 1-27. [CrossRef]

6. Roshani, M.; Shojaosadati, S.; Safdari, S.; Vasheghani-Farahani, E.; Mirjalili, K.; Manafi, Z. Bioleaching of molybdenum by two new thermophilic strains isolated and characterized. Iran. J. Chem. Chem. Eng. 2017, 36, 183-194. [CrossRef]

7. Ai, C.; McCarthy, S.; Liang, Y.; Rudrappa, D.; Qiu, G.; Blum, P. Evolution of copper arsenate resistance for enhanced enargite bioleaching using the extreme thermoacidophile Metallosphaera sedula. J. Ind. Microbiol. Biotechnol. 2017, 44, 1613-1625. [CrossRef] [PubMed]

8. Jalali, F.; Fakhar, J.; Zolfaghari, A. On using a new strain of Acidithiobacillus ferridurans for bioleaching of low-grade uranium. Sep. Sci. Technol. 2019, 55, 994-1004. [CrossRef]

9. Meng, X.; Zhao, H.; Sun, M.; Zhang, Y.; Zhang, Y.; Lv, X.; Kim, H.; Vainshtein, M.; Wang, S.; Qiu, G. The role of cupric ions in the oxidative dissolution process of marmatite: A dependence on $\mathrm{Cu}^{2+}$ concentration. Sci. Total Environ. $2019,675,213-223$. [CrossRef] [PubMed]

10. Zhao, Y.; Zhao, H.; Abashina, T.; Vainshtein, M. Review on arsenic removal from sulfide minerals: An emphasis on enargite and arsenopyrite. Miner. Eng. 2021, 172, 107133. [CrossRef] 
11. You, J.; Solongo, S.K.; Gomez-Flores, A.; Choi, S.; Zhao, H.; Urík, M.; Ilyas, S.; Kim, H. Intensified bioleaching of chalcopyrite concentrate using adapted mesophilic culture in continuous stirred tank reactors. Bioresour. Technol. 2020, 307, 123181. [CrossRef] [PubMed]

12. Ilyas, S.; Bhatti, H.N.; Bhatti, I.A.; Sheikh, M.A.; Ghauri, M.A. Bioleaching of metal ions from low grade sulphide ore: Process optimization by using orthogonal experimental array design. Afr. J. Biotechnol. 2010, 9, 2801-2810. [CrossRef]

13. Ilyas, S.; Chi, R.; Bhatti, H.N.; Bhatti, I.A.; Ghauri, M.A. Column bioleaching of low-grade mining ore containing high level of smithsonite, talc, sphaerocobaltite and azurite. Bioprocess Biosyst. Eng. 2011, 35, 433-440. [CrossRef] [PubMed]

14. Pronk, J.T.; Meijer, W.M.; Hazeu, W.; van Dijken, J.P.; Bos, P.; Kuenen, J.G. Growth of Thiobacillus ferrooxidans on Formic Acid. Appl. Environ. Microbiol. 1991, 57, 2057-2062. [CrossRef] [PubMed]

15. Pronk, J.T.; van Dijken, J.P.; Bos, P.; Kuenen, J.G. High Tield Method of Growing Thiobacillus ferrooxidans on Formate. Patent of South Africa ZA 923117B, 30 December 1992. Available online: https:/ / patents.google.com/patent/ZA923117B/ru (accessed on 15 November 2021).

16. Boden, R. Reclassification of Halothiobacillus hydrothermalis and Halothiobacillus halophilus to Guyparkeria gen. nov. in the Thioalkalibacteraceae fam. nov., with emended descriptions of the genus Halothiobacillus and family Halothiobacillaceae. Int. J. Syst. Evol. Microbiol. 2017, 67, 3919-3928. [CrossRef] [PubMed]

17. Johnson, P.A.; Quayle, J.R.; Kemp, M.; Large, P.; Peel, D.; Heptinstall, J. Microbial growth on C1 compounds. 6. Oxidation of methanol, formaldehyde and formate by methanol-grown Pseudomonas AM 1. Biochem. J. 1964, 93, 281-290. [CrossRef] [PubMed]

18. Schacterle, G.R.; Pollack, R.L. A simplified method for the quantitative assay of small amounts of protein in biologic material. Anal. Biochem. 1973, 51, 654-655. [CrossRef]

19. Yanishevskya, E.; Fokina, N.; Selivanova, E.; Kompanchenko, A.; Makarov, D.; Goryachev, A. Processing of Sulfide Copper-Nickel Ores from the Deposits in Murmansk Region by Heap Leaching. Minerals 2021, 11, 820. [CrossRef] 